UDC 378.011.3-051:62

DOI: $10.31470 / 2415-3729-2019-10-25-39$

\title{
The Formation of Professional Thinking for Future Technology Teachers
}

\author{
Anatolii Brekhunets \\ Doctor of Philosophy in Pedagogy (Ph.D), Associate Professor \\ Associate Professor of the Departament of Theory and Methods of \\ Technological \\ Education and Computer Graphics \\ Pereiaslav-Khmelnytskyi Hryhorii Skovoroda State Pedagogical \\ University \\ \30, Sukhomlynskyi Str., Pereiaslav-Khmelnytskyi, Kyiv Region, \\ Ukraine, 08401 \\ E-mail: savik.tv0607@gmail.com. \\ ORCID: 0000-0002-7935-5300
}

Date of receipt of the article: September 28, 2019 Article accepted for publication: December 02, 2019

\section{Формування професійного мислення у майбутніх учителів технологій}

\section{Анатолій Іванович Брехунець}

кандидат педагогічних наук, доцент

доцент кафедри теорії і методики технологічної освіти та комп'ютерної графіки

ДВНЗ «Переяслав-Хмельницький державний педагогічний університет імені Григорія Сковороди»

$\triangle$ вул. Сковороди, 30, м. Переяслав-Хмельницький, Київська обл., Україна, 08401

\section{Abstract}

Дата надходження статті: 28 вересня 2019 р. Стаття прийнята до друку: 02 грудня 2019 р.

The article discusses the problem of the formation of the future Technology teachers' professional thinking. The concept 
of «professional thinking of the Technology teacher» is clarified, which is considered as the features of the teacher's thinking, letting him/her perform professional and pedagogical tasks successfully at a high level of mastery: quickly, accurately solve both the ordinary and extraordinary tasks of teaching and upbringing students in an original way. It has been established that the professional training of Technology teachers is a multi-faceted and time-consuming process. On the one hand, the student must master various work operations and technological processes at the industrial level or close to it, and on the other hand it must have general pedagogical knowledge and methods of their sharing. The peculiarities of the formation of the future Technology teachers' professional thinking are determined by their activity specifics, which is defined by the goals, tasks, content, external and internal conditions, means, difficulties, features of the mental processes occurrence, motivation displays, the state of a person and a team towards the implementation of management and guidance. That is why the formation of the Technology teachers' professional thinking should be carried out in an integral system of educational process at a pedagogical institution of higher education, and the methods of teaching students technologies to solve pedagogical tasks should be widely used at training sessions and pedagogical practices, contributing to the professional thinking formation. Moreover the research proves the necessity of wider informational technologies elements' application with the use of computerized and audio-visual complexes as leading means and a leader, which allow synthesizing the intellectual components of professional thinking and activating its structural components development. The benefit of the article is the defined conditions for the formation of the future Technology teachers professional thinking, they are: a motivation, new means of mastering professional activity, a mental activity intensification, the scientifically substantiated selection of educational material, students' age possibilities and individual peculiarities. As a result, the article reveals the need to include the material that reflects the 
specifics of the future Technology teachers professional thinking formation to the content of their subject and psychological and pedagogical training, as well as to combine individual and collective forms of students' work in the process of forming a professional thinking and to carry out a step-by-step control and correction of the future Technology teacher professional thinking formation.

Key words: professional thinking, Technology teacher, individual approach, practical training, educational process, conditions.

\section{References}

1. Hura, T.Ie. (2014). Psykholohiia rozvytku profesiinoho myslennia u maibutnikh psykholohiv u protsesi fakhovoi pidhotovky [Psychology of the development of professional thinking of future psychologists during the voational training]. Doctor's thesis. Kyiv: National Pedagogical Dragomanov University [in Ukrainian].

2. Dzhelilova, L.R. (2008). Psykholohichni osoblyvosti rozvytku profesiinoho myslennia u maibutnikh vchyteliv pochatkovoi shkoly [Psychological peculiarities of the development of future primary school teachers professional thinking]. Candidate's thesis. Odesa: South Ukrainian national pedagogical university named after K. D. Ushynsky [in Ukrainian].

3. Kovalchuk, V.B. (2007). Pedahohichni umovy formuvannia profesiinoho myslennia maibutnikh fakhivtsiv ekonomichnoho profiliu u vyshchykh navchalnykh zakladakh [Pedagogical conditions of forming the professional thinking of future specialists of economic profile at higher educational institutions]. Candidate's thesis. Kyiv: Institute of Vocational Education and Training of Naesof Ukraine [in Ukrainian].

4. Kravets, R.A. (2011). Pedahohichni umovy formuvannia tvorchoho myslennia maibutnoho vchytelia inozemnoi movy u protsesi profesiinoi pidhotovky [Pedagogical conditions of creative thinking formation of the future foreign language teacher in the professional training process]. Candidate's thesis. Khmelnytskyi: Khmelnytskyi National University [in Ukrainian]. 
5. Lisnevska, A.L. (2011). Formuvannia profesiinoho myslennia maibutnikh televiziinykh reporteriv u protsesi fakhovoi pidhotovky [Formation of the professional thinking of future TV reporters in the professional training process]. Candidate's thesis. Luhansk: Luhansk Taras Shevchenko National University [in Ukrainian].

6. Lunov, V.Ie. (2013). Psykholohichni osoblyvosti stanovlennia profesiinoho myslennia osobystosti u systemi orhaniv vnutrishnikh sprav Ukrainy [Psychological peculiarities of the personality's professional thinking formation in the system of internal affairs of Ukraine]. Candidate's thesis. Odesa: Odessa National I.I.Mechnikov University [in Ukrainian].

7. Malii, N.M. (2011). Psykholoho-pedahohichni osoblyvosti rozvytku kreatyvnoi skladovoi profesiinoho myslennia u maibutnikh pedahohiv [Psychological and pedagogical peculiarities of the development of the creative component of the future teachers' professional thinking]. Candidate's thesis. Khmelnytskyi: Bohdan Khmelnytskyi National Academy of the State Border Guard Service of Ukraine [in Ukrainian].

8. Pavlenko, I.O. (2015). Formuvannia valeolohichnoho myslennia maibutnikh uchyteliv pryrodnychykh spetsialnostei $\mathrm{u}$ protsesi profesiinoi pidhotovky [Formation of valeological thinking of the future teachers of natural sciences in the process of vocational training]. Candidate's thesis. Pereiaslav-Khmelnytskyi: PereiaslavKhmelnytskyi Hryhorii Skovoroda State Pedagogical University [in Ukrainian].

9. Poviakel, N.I. (2004). Samorehuliatsiia profesiinoho myslennia v systemi fakhovoi pidhotovky praktychnykh psykholohiv [Selfregulation of professional thinking in the system of professional training of counsellors]. Doctor's thesis. Kyiv: National Pedagogical Dragomanov University [in Ukrainian].

10. Pryhodii, M.A. (2011). Suchasni aspekty pidhotovky vchyteliv tekhnolohii [Modern aspects of Technology teacher training]. Candidate's thesis. Chernihiv: Chernihiv National Pedagogical University named after T.H. Shevchenko. [in Ukrainian]. 
11. Rudenko, Yu.M. (2005) Udoskonalennia profesiinoho myslennia $\mathrm{v}$ kursantiv-pilotiv $\mathrm{u}$ protsesi vyvchennia dystsyplin pilotazhno-navihatsiinoho tsyklu [Cadets-pilots professional thinking perfection during studying the series of the aircraft instrumentation disciplines]. Candidate's thesis. Kharkiv: Ukrainian Engineering Pedagogics Academy [in Ukrainian].

12. Tarasova, O.V. (2010) Psykholohichni umovy rozvytku profesiinoho myslennia uchniv profesiino-tekhnichnykh navchalnykh zakladiv hirnychoho profiliu [Psychological conditions for the professional thinking development of students of vocational schools with the mining profile]. Kyiv: G.S. Kostiuk Institute of Psychology of the National Academy of Educational Sciences of Ukraine [in Ukrainian].

13. Shaida, O.H. (2014) Psykholohichni osoblyvosti stanovlennia profesiinoho myslennia maibutnikh uchyteliv humanitarnoho profiliu [Psychological peculiarities of professional thinking development of future teachers with the humanitarian profile] Candidate's thesis. Kharkiv: H.S. Skovoroda Kharkiv National Pedagogical Universit. [in Ukrainian].

\section{Вступ}

Сучасні соціально-економічні обставини розвитку українського суспільства висуває принципово нові вимоги до підготовки педагогічних кадрів, які передбачають якісні зміни стратегічних принципів навчання, перехід до нових пріоритетних цілей і завдань, посилення інноваційних процесів. Формування особистості вчителя $\epsilon$ однією з центральних проблем системи педагогічної освіти. У зв'язку з цим в центрі уваги більшості сучасних психолого-педагогічних дослідженьз проблеми вищої освіти $\epsilon$ питання: як забезпечити максимальний розвиток пізнавальних здібностей майбутніх учителів, як навчити студентів професійно мислити? Специфічність професійної діяльності вчителя вимагає відповідних конструктивних рішень у визначенні змісту, засобів і методів його професійної підготовки. 
У той же час, питання професійної творчої підготовки вчителя найменш розроблені і вивчені,а саме в цьому аспекті закладені великі можливості підвищення ефективності всього освітнього процесу, в тому числі технологічної підготовки.

Професійна підготовка вчителів технологій - процес багатобічний і трудомісткий. 3 одного боку, студент повинен опанувати різні трудові операції та технологічні процеси на рівні або близько до промислового, а з іншого - володіти загальними педагогічними знаннями і методами їх передачі.

Безсумнівно, що професійна підготовка вчителя технологій повинна здійснюватися не ізольовано, а в цілісному освітньому процесі, що розуміється як складно організована система аудиторної і позааудиторної роботи студентів.

Тенденція загальної комп'ютеризації актуалізує розвиток інтелектуально-творчого та технічного потенціалу особистості, в якому все більшу роль набуває предметна підготовка, що передбачає формування не тільки предметних знань, умінь і навичок, а й розвинене наукове мислення у відповідній галузі знань.

Мислення в освітньому процесі є головним засобом всього пізнання, оскільки пов'язує безпосереднє, опосередковане і узагальнене знання людини про навколишній світ, явища, події.

Однак в структуру професійного мислення вчителя входить i загально педагогічне мислення як одне із стрижневих, основоположних компонентів пізнавальної діяльності вчителя, що виражається в специфічній професійній спрямованості мислення і що виявляється в педагогічних, уміннях. Аналіз існуючої спеціальної літератури показав, що цей аспект проблеми не знайшов належного відображення в теорії і практиці педагогіки.

Вирішення протиріччя між потребами практики в підготовці майбутнього вчителя технологій 3 високим рівнем професійного мислення і не розробленістю іï основ, дозволило б забезпечити можливість підвищення якості підготовки вчителів технологій.

Теоретико-методологічним основам розвитку предметного мислення вчителя присвячені спеціальні дослідження, 
педагогів і психологів Г.А. Балла, Ю.К. Бабансько, Д. Брунера, П.Я. Гальперіна, В.В. Давидова, 3.І. Калмикова, В.А. Крутецкого, А.Н. Леонтьєва, І.Я. Лернера, М.Н. Скаткина, Л.М. Фрідмана та ін.

Ключовими $\epsilon$ наукові праці 3 розвитку професійного мислення В.П. Андронова, А.А. Баталова, М.М. Кашапова, Ю.К. Корнілова, А.К. Маркової, 3.О. Решетової.

Особливості формування професійного мислення фахівців різних галузей і напрямів вивчали: А.Л. Лісневська (формування професійного мислення майбутніх телевізійних репортерів у процесі фахової підготовки) (Лісневська, 2011); В.Б. Ковальчук (педагогічні умови формування професійного мислення майбутніх фахівців економічного профілю у вищих навчальних закладах) (Ковальчук, 2007); О.В. Тарасова (психологічні умови розвитку професійного мислення учнів професійно-технічних навчальних закладів гірничого профілю) (Тарасова, 2010); Т.С Гура (психологія розвитку професійного мислення у майбутніх психологів у процесі фахової підготовки) (Гура, 2014); Ю.М. Руденко (удосконалення професійного мислення в курсантів-пілотів у процесі вивчення дисциплін пілотажно-навігаційного циклу) (Руденко, 2005); Н.І. Пов'якель (саморегуляція професійного мислення в системі фахової підготовки практичних психологів) (Пов'якель, 2004); В.С. Луньов (психологічні особливості становлення професійного мислення особистості у системі органів внутрішніх справ України) (Луньов, 2013); О.Г. Шайда (психологічні особливості становлення професійного мислення майбутніх учителів гуманітарного профілю) (Шайда, 2014); Н.М. Малій (психолого-педагогічні особливості розвитку креативної складової професійного мислення у майбутніх педагогів) (Малій, 2011); Л.Р. Джелілова (психологічні особливості розвитку професійного мислення у майбутніх вчителів початкової школи) (Джелілова, 2008); М.А. Пригодій (аналіз сучасних аспектів підготовки вчителів технологій) (Пригодій, 2011); І.О. Павленко (формування валеологічного мислення майбутніх учителів природничих 
спеціальностей у процесі професійної підготовки) (Павленко, 2015); Р.А. Кравець (педагогічні умови формування творчого мислення майбутнього вчителя іноземної мови у процесі професійної підготовки) (Кравець, 2011).

Цілеспрямована робота з розвитку професійного мислення у майбутніх учителів технологій сприятиме набуттю студентами знань, умінь і навичок у педагогічній сфері, підвищить творчий рівень особистості і досвід самостійної роботи. Але для цього потрібно змінити зміст і методичні аспекти в підготовці вчителів технологій, формувати професійне мислення, з огляду на специфіку предмета і праці викладача.

Мета статті - визначити особливості формування професійного мислення у майбутніх учителів технологій.

\section{Матеріал і методи дослідження}

У процесі дослідження застосовано наступні методи: аналіз, порівняння, узагальнення та систематизація.

\section{Результати та їх обговорення}

Професійна підготовка майбутніх учителів розпочинається саме під час навчання у закладі вищої освіти, в цей час відбувається формування основ трудової діяльності, відбувається професіоналізація пам'яті, мислення, сприйняття та інших вищих психічних функцій.

У сучасних педагогічних дослідженнях існує широке коло різних точок зору на проблематику формування професійного мислення у майбутніх учителів технологій.

За визначенням Я.В. Крушельницької професійне мислення - це інтелектуальна діяльність щодо розв' язання професійних завдань. Високий рівень професіоналізму працівника пов'язаний 3 теоретичним, творчим мисленням і розвиненим практичним інтелектом.

Досліджуючи психологічний зміст професійного мислення особистості О.В. Тарасова визначає професійне мислення як мисленнєву діяльність, яка спрямована на розв'язання професійних задач у певній предметній галузі. Якщо специфіка 
професійного мислення залежить від своєрідності задач, які розв'язуються різними фахівцями, то якість професійної діяльності чи рівень професіоналізму залежить від розвиненості професійного мислення (Тарасова, 2010).

Таким чином, можна констатувати, що професійне мислення учителя технологій - це особливості мислення учителя, що дозволяють йому успішно виконувати професійно-педагогічні завдання на високому рівні майстерності: швидко, точно, оригінально вирішувати як ординарні, так і неординарні завдання навчання та виховання учнів.

Для підвищення ефективності професійної підготовки учителів технологій необхідно наголосити на формуванні професійного мислення як складової частини системи професійної освіти.

Встановлені основні характеристики професійного мислення, до яких належать: активність та ініціативність; пошуковий та аналітико-синтетичний характер; глибина і широта; логічність і організованість; доказовість; несуперечливість; здатність мислити при «інформаційних порожнечах»; вміння висувати гіпотези і ретельно досліджувати їх; винахідливість; гнучкість; швидкість; практичність; ясність; стійкість; прогностичність; креативність; критичність.

На основі аналізу психолого-педагогічних досліджень встановлено, що найчастіше професійна підготовка майбутніх учителів здійснюється на засадах особистісно орієнтованого, компетентнісного та діяльнісного підходах. Цей факт обумовлений тим, що успіх в діяльності фахівця залежить перш за все від якісних особливостей і рівня процесів мислення.

Тому важливо сформувати розумову діяльність майбутніх учителів технологій 3 таким якостями, як: системність, диференційованість; інтегрованість, постійну i загальну спрямованість на сферу технологічної освіти.

Разом $з$ тим, слід наголосити, що в системі вищої педагогічної освіти на сьогоднішній день задача цілеспрямованого форму- 
вання професійного мислення чітко не усвідомлена і не сформульована як одна 3 пріоритетних задачпрофесійної підготовки учителів технологій. Лише з накопиченням досвіду роботи мислення фахівця в тій чи іншій мірі набуває професійно важливих якісних характеристик.

Таким чином, професійне мислення - це запорука успіху майбутнього вчителя, в досягненні якого одним 3 головних, цінних для самої особистості орієнтирів повинно стати професіоналізація мислення.

Особливості формування професійного мислення майбутнього учителя технологій визначаються специфікою його діяльністю, що визначається цілями, завданнями, змістом, зовнішніми і внутрішніми умовами, засобами, труднощам, особливостями протікання психічних процесів, проявами мотивації, станом особистості і колективу щодо здійснення управління i керівництва.

Здійснення формування професійного мислення у майбутніх учителів технологій відбувається в системі їх підготовку до професійної діяльності, при цьому необхідно дотримуватись наступних умов:

1) посилити мотивацію студентів до опанування основами професії вчителя за рахунок: прагнення до самоактуалізації своєї особистості; прагнення до самовираження і самопізнання в процесі навчання;

2) запропонувати студентам нові і більш ефективні засоби для реалізації своїх установок на активне оволодіння новими видами професійної діяльності, знаннями і вміннями;

3) забезпечити більшу відповідність організаційних форм і засобів навчання особливостям освітнього процесу у загальноосвітньому навчальному закладі;

4) інтенсифікувати розумову діяльність майбутнього вчителя технологій за рахунок більш раціонального використання часу навчального заняття, інтенсифікації спілкування студентів 3 викладачем та студентів між собою; 
5) забезпечити науково обгрунтований відбір навчального матеріалу, що підлягає засвоєнню (на основі його логічного аналізу і виділення основного (інваріантного) змісту та питань, що є актуальними для конкретного студента 3 урахуванням його індивідуальних прагнень та особливостей);

6) врахувати вікові можливості та індивідуальні особливості студентів.

\section{Висновки}

Результати проведеного аналізу дозволяють зробити ряд практичних рекомендацій, виконання яких сприятиме підвищенню ефективності формування професійного мислення у майбутніх учителів технологій. По-перше, формування професійного мислення вчителя необхідно здійснювати в цілісній системі освітнього процесу педагогічного закладу вищої освіти; по-друге, на навчальних заняттях та педагогічних практиках широко використовувати прийоми навчання студентів технологіям рішення педагогічних завдань, що сприяють формуванню професійного мислення; по-третє, ширше застосовувати елементи інформаційних технологій 3 використанням в якості ведучого і керівника засобу комп'ютеризованих і аудіовізуальних комплексів, що дозволяють здійснювати синтез інтелектуальних складових професійного мислення i активізувати розвиток його структурних компонентів; по-четверте, включати в зміст предметної і психолого-педагогічної підготовки майбутніх учителів технологій матеріал, що відображає специфіку формування їх професійного мислення; по-п'яте, поєднувати індивідуальні і колективні форми роботи студентів у процесі формування професійного мислення та здійснювати поетапний контроль і корекцію формування професійного мислення майбутнього вчителя технологій.

Перспективи подальших наукових досліджень полягають у проведенні експериментальної перевірки висунутих теоретичних положень з проблеми формування професійного мислення у майбутніх учителів технологій. 


\section{Література}

1. Гура Т.С. Психологія розвитку професійного мислення у майбутніх психологів у процесі фахової підготовки: дис. д-ра психол. наук: 19.00.07 / Нац. пед. ун-т ім. М.П. Драгоманова. Київ, 2014. $400 \mathrm{c}$.

2. Джелілова Л.Р. Психологічні особливості розвитку професійного мислення у майбутніх вчителів початкової школи : дис... канд. наук: 19.00.07 / Південноукраїнський державний педагогічний університет ім. К.Д. Ушинського. Одеса, 2008.

3. Ковальчук В.Б. Педагогічні умови формування професійного мислення майбутніх фахівців економічного профілю у вищих навчальних закладах : дис... канд. наук: 13.00.04 / Інститут професійнотехнічної освіти Академії педагогічних наук України. Київ, 2007.

4. Кравець Р.А. Педагогічні умови формування творчого мислення майбутнього вчителя іноземної мови у процесі професійної підготовки: дис... канд. наук: 13.00.04 / Хмельниц. нац. ун-т. Хмельницький, 2011.

5. Лісневська А.Л. Формування професійного мислення майбутніх телевізійних репортерів у процесі фахової підготовки : дис... канд. наук: 13.00.04 / Луган. нац. ун-т ім. Т.Шевченка. Луганськ, 2011.

6. Луньов В.С. Психологічні особливості становлення професійного мислення особистості у системі органів внутрішніх справ України : дис...канд. психол. наук: 19.00.01, Одес. нац. ун-т ім. I.I. Мечникова. Одеса, 2013. 290 с.

7. Малій Н.M. Психолого-педагогічні особливості розвитку креативної складової професійного мислення у майбутніх педагогів : дис... канд. наук: 19.00.07 / Нац. акад. Держ. прикордон. служби України ім. Б. Хмельницького. Хмельницький, 2011.

8. Павленко I.O. Формування валеологічного мислення майбутніх учителів природничих спеціальностей у процесі професійної підготовки :дис...канд. пед. наук: 13.00.04 / ДВНЗ «Переяслав-Хмельниц. держ. пед. ун-т ім. Григорія Сковороди». Переяслав-Хмельницький, 2015. 200 с. 
9. Пов’якель Н.I. Саморегуляція професійного мислення в системі фахової підготовки практичних психологів: дис... д-ра психол. наук: 19.00.07, Національний педагогічний ун-т ім. М.П. Драгоманова. Київ, 2004.

10. Пригодій M.А. Сучасні аспекти підготовки вчителів технологій: монографія. Чернігів: ЧНПУ імені Т.Г. Шевченка, 2011. 384 c.

11. Руденко Ю.М. Удосконалення професійного мислення в курсантів-пілотів у процесі вивчення дисциплін пілотажнонавігаційного циклу : дис... канд. наук: 13.00.02 / Українська інженерно-педагогічна академія. Харків, 2005.

12. Тарасова О.В. Психологічні умови розвитку професійного мислення учнів професійно-технічних навчальних закладів гірничого профілю : дис... канд. наук: 19.00.07 / Інститут психології імені Г.С. Костюка НАПН України. Київ, 2010.

13. Шайда О.Г. Психологічні особливості становлення професійного мислення майбутніх учителів гуманітарного профілю: дис. канд. психол. наук: 19.00.07 / Харків. нац. пед. ун-т ім. Г.С. Сковороди. Харків, 2014. 100 с.

\section{Брехунець A.I.}

\section{Формування професійного мислення у майбутніх учителів технологій}

\section{Анотація}

У статті розглядається питання про формування професійного мислення у майбутніх учителів технологій. Уточнено поняття «професійне мислення учителя технологій», що визначається як особливості мислення учителя, що дозволяють йому успішно виконувати професійно-педагогічні завдання на високому рівні майстерності: швидко, точно, оригінально вирішувати як ординарні, так і неординарні завдання навчання та виховання 
учнів. Встановлено, що формування професійного мислення вчителя необхідно здійснювати в цілісній системі освітнього процесу педагогічного закладу вищої освіти, при цьому на навчальних заняттях та педагогічних практиках широко використовувати прийоми навчання студентів технологіям рішення педагогічних завдань, що сприяють формуванню професійного мислення. Доведено необхідність більш широкого застосування елементів інформаційних технологій $з$ використанням в якості ведучого і керівника засобу комп'ютеризованих і аудіовізуальних комплексів, що дозволяють здійснювати синтез інтелектуальних складових професійного мислення і активізувати розвиток його структурних компонентів. Розкрито необхідність включати в зміст предметної і психолого-педагогічної підготовки майбутніх учителів технологій матеріал, що відображає специфіку формування їх професійного мислення, a також поєднувати індивідуальні і колективні форми роботи студентів у процесі формування професійного мислення та здійснювати поетапний контроль і корекцію формування професійного мислення майбутнього вчителя технологій.

Ключові слова: професійне мислення, учитель технологій, індивідуальний підхід, практичне навчання, освітній процес, умови.

\section{Брехунец А.И.}

\section{Формирование профессионального мышления у будущих учителей технологий}

\section{Аннотация}

В статье рассматривается вопрос о формировании профессионального мышления у будущих учителей технологий. Уточнено понятие «профессиональное мышление учителя технологий», которое определяется как особенности мышления учителя, 
которые позволяют ему успешно выполнять профессионально педагогические задание на высоком уровне мастерства: быстро, точно, оригинально решать, как ординарные, так и неординарные, задания учебы и воспитания учеников. Установлено, что формирование профессионального мышления учителя необходимо осуществлять в целостной системе образовательного процесса педагогического заведения высшего образования, при этом на учебных занятиях и педагогических практиках широко использовать приемы учебы студентов технологиям решения педагогических заданий, которые способствуют формированию профессионального мышления. Доказана необходимость более широкого применения элементов информационных технологий с использованием в качестве ведущего и руководителя средства компьютеризованных и аудиовизуальных комплексов, которые позволяют осуществлять синтез интеллектуальных составляющих профессионального мышления и активизировать развитие его структурных компонентов. Раскрыта необходимость включать в содержание предметной и психолого-педагогической подготовки будущих учителей технологий материал, который отображает специфику формирования их профессионального мышления, а также совмещать индивидуальные и коллективные формы работы студентов в процессе формирования профессионального мышления и осуществлять поэтапный контроль и коррекцию формирования профессионального мышления будущего учителя технологий.

Ключевые слова: профессиональное мышления, учитель технологий, индивидуальный подход, практическая учеба, образовательный процесс, условия. 